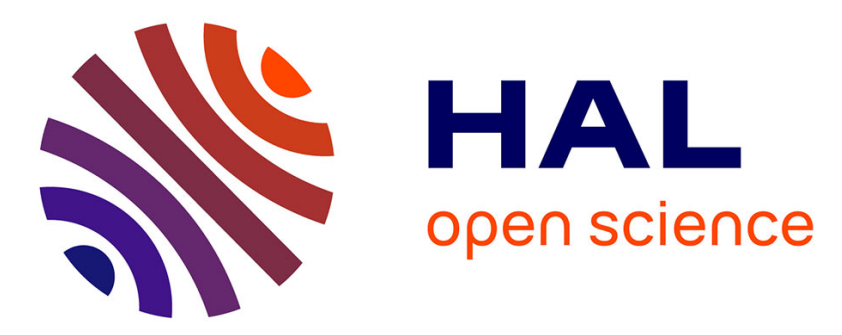

\title{
Powders of Chromium and Chromium Carbides of Different Morphology and Narrow Size Distribution
}

Sophie Loubière, Christophe Laurent, Jean-Pierre Bonino, Abel Rousset

\section{To cite this version:}

Sophie Loubière, Christophe Laurent, Jean-Pierre Bonino, Abel Rousset. Powders of Chromium and Chromium Carbides of Different Morphology and Narrow Size Distribution. Materials Research Bulletin, 1998, vol. 33, pp. 935-944. 10.1016/S0025-5408(98)00062-2 . hal-00960612

\section{HAL Id: hal-00960612 https://hal.science/hal-00960612}

Submitted on 18 Mar 2014

HAL is a multi-disciplinary open access archive for the deposit and dissemination of scientific research documents, whether they are published or not. The documents may come from teaching and research institutions in France or abroad, or from public or private research centers.
L'archive ouverte pluridisciplinaire HAL, est destinée au dépôt et à la diffusion de documents scientifiques de niveau recherche, publiés ou non, émanant des établissements d'enseignement et de recherche français ou étrangers, des laboratoires publics ou privés. 


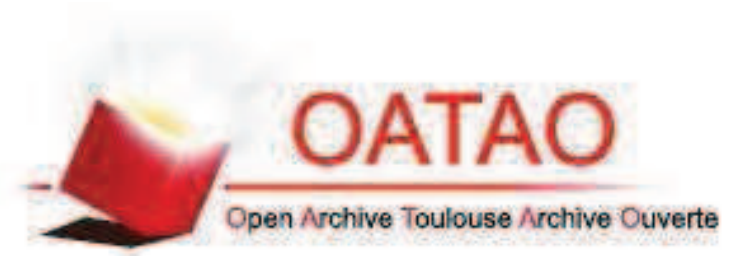

\section{Open Archive Toulouse Archive Ouverte (OATAO)}

OATAO is an open access repository that collects the work of Toulouse researchers and makes it freely available over the web where possible.

This is an author-deposited version published in: http://oatao.univ-toulouse.fr/ Eprints ID: 11134

To link to this article : DOI:10.1016/S0025-5408(98)00062-2

URL: http://dx.doi.org/10.1016/S0025-5408(98)00062-2

\section{To cite this version:}

Loubière, Sophie and Laurent, Christophe and Bonino, Jean-Pierre and Rousset, Abel Powders of Chromium and Chromium Carbides of Different Morphology and Narrow Size Distribution. (1998) Materials Research Bulletin, vol. 33 (n ${ }^{\circ}$ 6). pp. 935-944. ISSN 0025-5408

Any correspondence concerning this service should be sent to the repository administrator: staff-oatao@,listes.diff.inp-toulouse.fr 


\title{
POWDERS OF CHROMIUM AND CHROMIUM CARBIDES OF DIFFERENT MORPHOLOGY AND NARROW SIZE DISTRIBUTION
}

\author{
S. Loubière, Ch. Laurent,* J.P. Bonino, and A. Rousset \\ Laboratoire de Chimie des Matériaux Inorganiques, ESA CNRS 5070, \\ Université Paul-Sabatier, 31062 Toulouse Cedex 4, France
}

\begin{abstract}
Powders of $\mathrm{Cr}$ and $\mathrm{Cr}$ carbides $\left(\mathrm{Cr}_{2} \mathrm{C}, \mathrm{Cr}_{7} \mathrm{C}_{3}\right.$, and $\left.\mathrm{Cr}_{23} \mathrm{C}_{6}\right)$ have been prepared by hydrogen reduction of $\mathrm{CrO}_{1.9}$ and $\mathrm{Cr}_{3} \mathrm{C}_{2}$ powders of different morphology, texture and specific surface area. The $\mathrm{Cr}$ and $\mathrm{Cr}$ carbides particles have the morphology of the parent compound and a narrow size distribution. Depending on the shape, the average size is of the order of some micrometers or some tens of micrometers. Starting with $\mathrm{Cr}_{3} \mathrm{C}_{2}$ allows the preparation of $\mathrm{Cr}$ powders at a temperature $\left(1000^{\circ} \mathrm{C}\right)$ markedly lower than that required when $\mathrm{CrO}_{1.9}$ is used as the precursor $\left(1300^{\circ} \mathrm{C}\right)$. However, a $\mathrm{Cr}_{3} \mathrm{C}_{2}$ specific surface area of the order of $10 \mathrm{~m}^{2} / \mathrm{g}$ is necessary to achieve this within a reasonably short time (6 to $12 \mathrm{~h}$ ). Powders of the lower carbides are prepared by using a milder hydrogen thermal treatment.
\end{abstract}

KEYWORDS: A. carbides, A. oxides

\section{INTRODUCTION}

Micrometric metal and carbide powders of controlled morphology and uniform size distribution are of considerable interest for industrial applications such as conductive inks or pastes for electronic materials and also for powder metallurgy [1-4]. Metals such as Fe, Co, $\mathrm{Ni}, \mathrm{Cu}$, and $\mathrm{Ru}$ and the noble metals have been prepared by reduction of the appropriate precursor compounds, using notably the so-called polyol process [5], the precipitation from homogeneous solutions [6], and the microwave-hydrothermal method [7]. An alternative to

*To whom correspondence should be addressed. 
these wet routes is the reduction in $\mathrm{H}_{2}$ or $\mathrm{CO}$ atmosphere of solid precursors which already are monodispersed and of a definite shape. As pointed out by Matijevic [6], such conversions can take place without a loss in the morphology or the dispersion of the final products only under carefully controlled conditions. Thus, in contrast to the above-mentioned metals, a $\mathrm{Cr}$ powder is very difficult to obtain by such methods, because of the difficulty in reducing $\mathrm{Cr}_{2} \mathrm{O}_{3}$. Thibaudon et al. [8] have shown that decarburization in hydrogen of $\mathrm{Cr}_{3} \mathrm{C}_{2}$ yields the lower carbides $\mathrm{Cr}_{7} \mathrm{C}_{3}$ and $\mathrm{Cr}_{23} \mathrm{C}_{6}$ and even $\mathrm{Cr}$ if the treatment is severe enough $\left(1000^{\circ} \mathrm{C}\right.$, $150 \mathrm{~h}$ ); however, they did not investigate powder characteristics such as morphology and particle size.

Lerch and Rousset [9] have shown that the pseudomorphic decomposition in air of chromium oxalates of controlled morphology (needles, rods, polyhedra, and spheres) could lead to metastable chromium oxides of general formula $\mathrm{CrO}_{1.9}$ with the same morphology. These products have a specific surface area in the $200-350 \mathrm{~m}^{2} / \mathrm{g}$ range and it has been shown in previous works $[10,11]$ that they are interesting precursors for the synthesis of the stable $\mathrm{Cr}_{3} \mathrm{C}_{2}$ and metastable $\mathrm{Cr}_{3} \mathrm{C}_{2-\mathrm{x}}$ phases of controlled morphology while combining the advantages of moderate preparation temperature $\left(700^{\circ} \mathrm{C}\right)$ and high yield. The aim of the present paper is to investigate the synthesis of $\mathrm{Cr}_{2} \mathrm{C}, \mathrm{Cr}_{7} \mathrm{C}_{3}, \mathrm{Cr}_{23} \mathrm{C}_{6}$, and $\mathrm{Cr}$ powders of different morphology and narrow size distribution using $\mathrm{CrO}_{1.9}$ and $\mathrm{Cr}_{3} \mathrm{C}_{2}$ as starting materials.

\section{EXPERIMENTAL}

The synthesis of the oxalates and $\mathrm{CrO}_{1.9}$ oxides was described in detail in previous papers $[9,10]$. Briefly, ammonium trioxalatochromate(III) $\left(\mathrm{NH}_{4}\right)_{3}\left[\mathrm{Cr}\left(\mathrm{C}_{2} \mathrm{O}_{4}\right)_{3}\right]$ was prepared by mixing the appropriate amounts of ammonium oxalate $\left(\mathrm{NH}_{4}\right)_{2}\left(\mathrm{C}_{2} \mathrm{O}_{4}\right) \cdot 2 \mathrm{H}_{2} \mathrm{O}$ and chromium(III) nitrate $\mathrm{Cr}\left(\mathrm{NO}_{3}\right)_{3} \cdot 9 \mathrm{H}_{2} \mathrm{O}$ in an aqueous solution heated at $60^{\circ} \mathrm{C}$. The clear solution obtained was cooled to room temperature and rapidly added to an organic solution (equivolumic mixture of either acetone and methanol or ethanol and ethyleneglycol), in which precipitation occurred immediately. Oxalates of different morphology, namely, needles, rods, polyhedra, and spheres (more precisely, spherical agglomerates of platelets), were obtained depending

TABLE 1

Morphological and Microstructural Characteristics of the Starting Oxide and Carbide Powders

\begin{tabular}{llcc}
\hline Nature & Shape & $\mathrm{S}_{\mathrm{w}}\left(\mathrm{m}^{2} / \mathrm{g}\right)$ & Average size $^{a}(\mu \mathrm{m})$ \\
\hline $\mathrm{CrO}_{1.9}$ & polyhedra & 185 & 30 \\
$\mathrm{CrO}_{1.9}$ & spheres & 320 & 9 \\
$\mathrm{Cr}_{3} \mathrm{C}_{2}$ & needles & 10.0 & $70 \times 10$ \\
$\mathrm{Cr}_{3} \mathrm{C}_{2}$ & rods & 10.0 & $70 \times 20$ \\
$\mathrm{Cr}_{3} \mathrm{C}_{2}$ & polyhedra & 9.1 & 20 \\
$\mathrm{Cr}_{3} \mathrm{C}_{2}$ & spheres & 12.0 & 8 \\
$\mathrm{Cr}_{3} \mathrm{C}_{2}$ & spheres & 4.0 & 8 \\
$\mathrm{Cr}_{3} \mathrm{C}_{2}$ & spheres & 1.0 & 8 \\
\hline
\end{tabular}

$\mathrm{S}_{\mathrm{w}}$ : specific surface area.

${ }^{a}$ Determined from measurements of SEM images. 

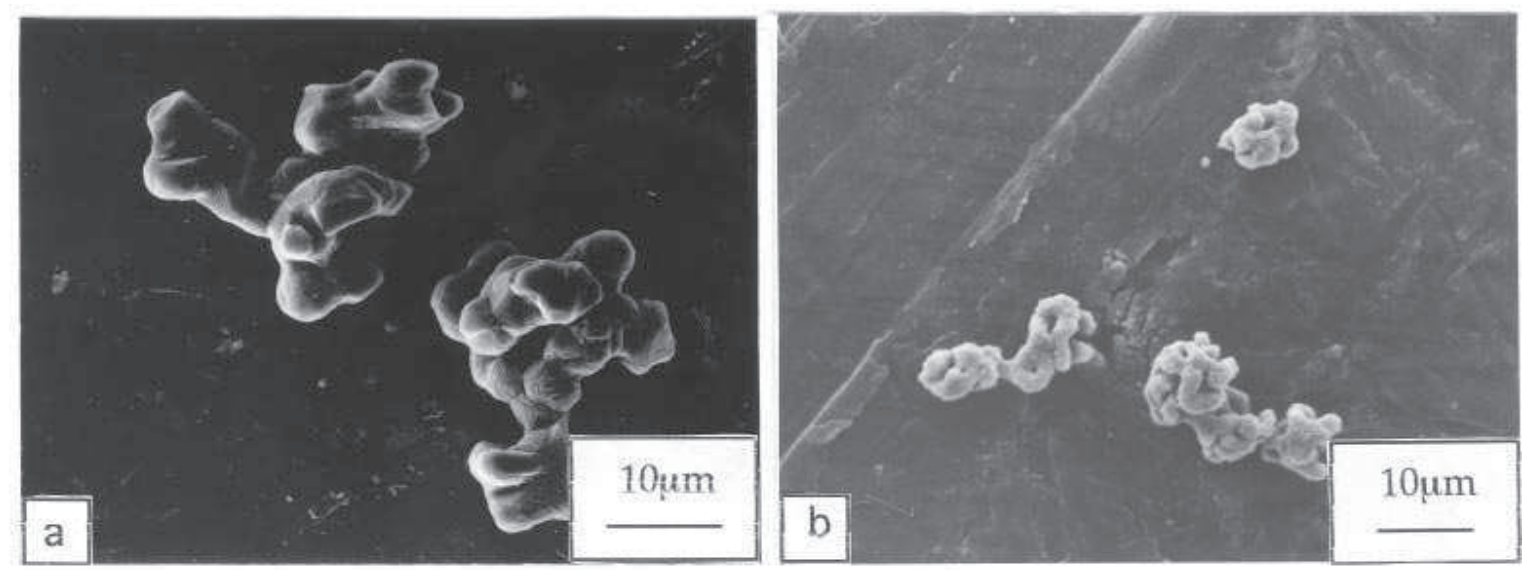

FIG. 1

SEM images showing $\mathrm{Cr}$ particles obtained from the polyhedral (a) and spherical (b) $\mathrm{CrO}_{1.9}$ oxides after a $\mathrm{H}_{2}$ reduction at $1300^{\circ} \mathrm{C}$ for $6 \mathrm{~h}$.

on the relative proportions of aqueous and organic solutions and on the nature of the latter. After filtering and ethanol washing, the powders were oven dried at $90^{\circ} \mathrm{C}$ for $48 \mathrm{~h}$.

Powders of the metastable chromium oxide $\mathrm{CrO}_{1.9}$ were prepared by decomposition in air at $300^{\circ} \mathrm{C}$ of the chromium oxalates of different morphology $[9,10]$. The so-obtained oxides, which have the same morphology as the parent oxalates, were heat-treated for $2 \mathrm{~h}$ at $700^{\circ} \mathrm{C}$ in an $\mathrm{H}_{2}-\mathrm{CH}_{4}$ atmosphere $\left(10 \mathrm{~mol}_{0} \mathrm{CH}_{4}\right)$ to yield $\mathrm{Cr}_{3} \mathrm{C}_{2}$ powders with the same morphology and a specific surface area of the order of $10 \mathrm{~m}^{2} / \mathrm{g}$ as described elsewhere [10]. The gas flow was dried on $\mathrm{P}_{2} \mathrm{O}_{5}$ and its composition was monitored using mass flow controllers. Other specimens of the spherical $\mathrm{Cr}_{3} \mathrm{C}_{2}$ were prepared by treatments at 800 and $1000^{\circ} \mathrm{C}$ to obtain powders with a lower specific surface area (4 and $1 \mathrm{~m}^{2} / \mathrm{g}$, respectively).

The $\mathrm{Cr}_{3} \mathrm{C}_{2}$ powders as well as the polyhedral and spherical $\mathrm{CrO}_{1.9}$ specimens were then submitted to a treatment in pure, dry $\mathrm{H}_{2}$ at different temperatures and for different times as required for the study. The morphological and microstructural features of all the starting powders are reported in Table 1.

TABLE 2

Phases Detected by XRD After Treating the Spherical $\mathrm{Cr}_{3} \mathrm{C}_{2}$ Powders in $\mathrm{H}_{2}$ for $2 \mathrm{~h}$ at Different Temperatures

\begin{tabular}{cccc}
\hline Temperature $\left({ }^{\circ} \mathrm{C}\right)$ & $\mathrm{S} 1$ & $\mathrm{~S} 4$ & $\mathrm{~S} 12$ \\
\hline 500 & $\mathrm{Cr}_{3} \mathrm{C}_{2}$ & $\mathrm{Cr}_{3} \mathrm{C}_{2}$ & $\mathrm{Cr}_{3} \mathrm{C}_{2}$ \\
600 & $\mathrm{Cr}_{3} \mathrm{C}_{2}$ & $\mathrm{Cr}_{3} \mathrm{C}_{2}$ & $\mathrm{Cr}_{3} \mathrm{C}_{2}+\mathrm{Cr}_{2} \mathrm{C}$ \\
650 & $\mathrm{Cr}_{3} \mathrm{C}_{2}$ & $\mathrm{Cr}_{3} \mathrm{C}_{2}$ & $\mathrm{Cr}_{2} \mathrm{C}$ \\
700 & $\mathrm{Cr}_{3} \mathrm{C}_{2}$ & $\mathrm{Cr}_{3} \mathrm{C}_{2}$ & $\mathrm{Cr}_{2} \mathrm{C}+\mathrm{Cr}_{7} \mathrm{C}_{3}$ \\
800 & $\mathrm{Cr}_{3} \mathrm{C}_{2}$ & $\mathrm{Cr}_{3} \mathrm{C}_{2}+\mathrm{Cr}_{7} \mathrm{C}_{3}$ & $\mathrm{Cr}_{2} \mathrm{C}+\mathrm{Cr}_{7} \mathrm{C}_{3}$ \\
850 & $\mathrm{Cr}_{3} \mathrm{C}_{2}$ & $\mathrm{Cr}_{3} \mathrm{C}_{2}+\mathrm{Cr}_{7} \mathrm{C}_{3}$ & $\mathrm{Cr}_{7} \mathrm{C}_{3}$ \\
900 & $\mathrm{Cr}_{3} \mathrm{C}_{2}+\mathrm{Cr}_{7} \mathrm{C}_{3}$ & $\mathrm{Cr}_{3} \mathrm{C}_{2}+\mathrm{Cr}_{7} \mathrm{C}_{3}$ & $\mathrm{Cr}_{7} \mathrm{C}_{3}+\mathrm{Cr}_{23} \mathrm{C}_{6}$ \\
950 & $\mathrm{Cr}_{3} \mathrm{C}_{2}+\mathrm{Cr}_{7} \mathrm{C}_{3}$ & $\mathrm{Cr}_{7} \mathrm{C}_{3}$ & $\mathrm{Cr}_{7} \mathrm{C}_{3}+\mathrm{Cr}_{23} \mathrm{C}_{6}$ \\
1000 & $\mathrm{Cr}_{3} \mathrm{C}_{2}+\mathrm{Cr}_{7} \mathrm{C}_{3}$ & $\mathrm{Cr}_{7} \mathrm{C}_{3}$ & $\mathrm{Cr}_{23} \mathrm{C}_{6}$ \\
\hline
\end{tabular}




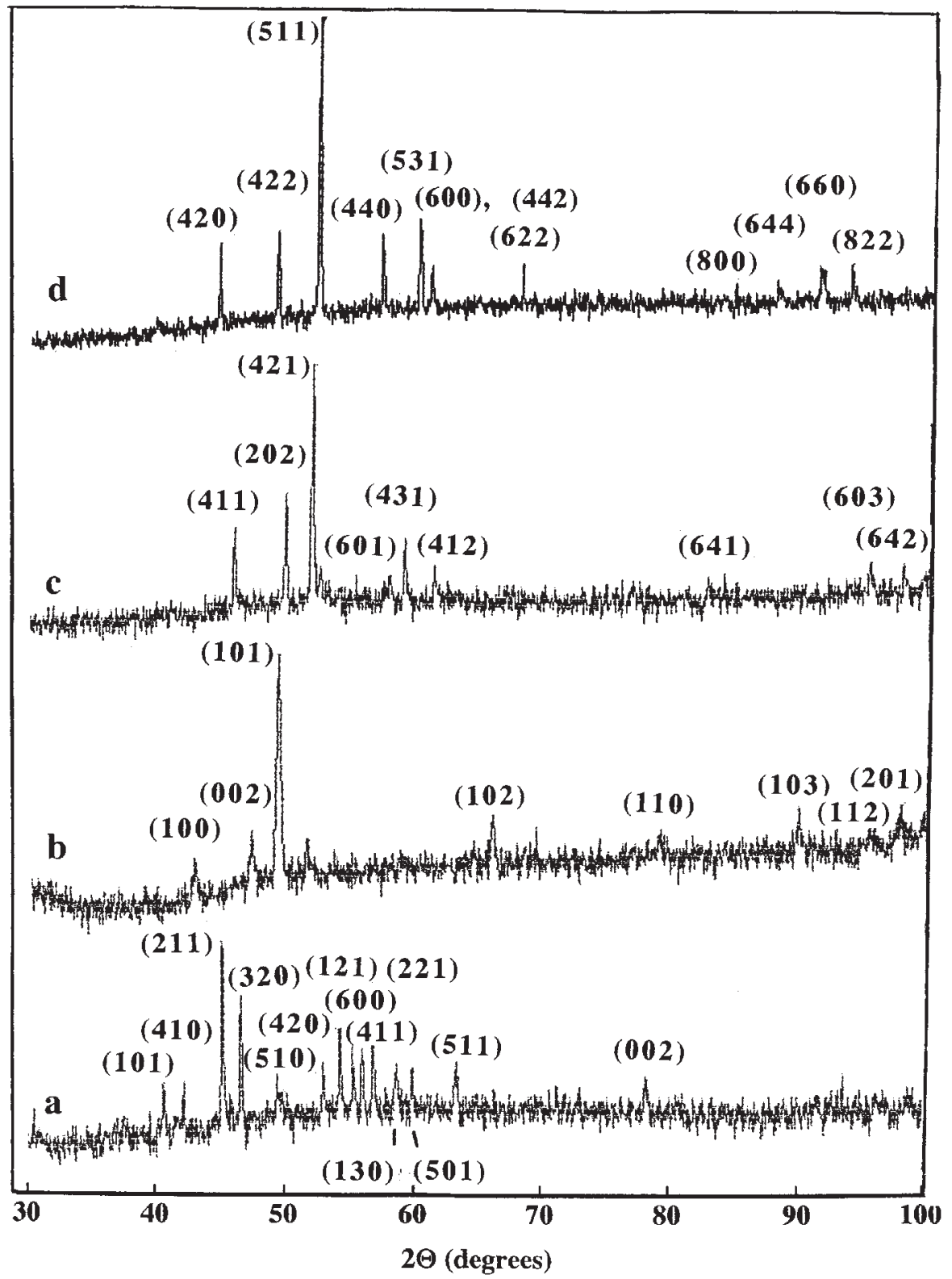

FIG. 2

XRD patterns of the products obtained from the $\mathrm{Cr}_{3} \mathrm{C}_{2}$ powder $\mathrm{S} 12$ heat-treated in $\mathrm{H}_{2}$ for $2 \mathrm{~h}$ at (a) $500^{\circ} \mathrm{C}\left(\mathrm{Cr}_{3} \mathrm{C}_{2}\right)$, (b) $650^{\circ} \mathrm{C}\left(\mathrm{Cr}_{2} \mathrm{C}\right)$, (c) $850^{\circ} \mathrm{C}\left(\mathrm{Cr}_{7} \mathrm{C}_{3}\right)$, and (d) $1000^{\circ} \mathrm{C}\left(\mathrm{Cr}_{23} \mathrm{C}_{6}\right)$.

The resulting materials were studied by scanning electron microscopy (SEM) and X-ray diffraction (XRD) using Co K $\alpha$ radiation $(\lambda=0.17902 \mathrm{~nm})$. The specific surface areas were measured by the BET method using $\mathrm{N}_{2}$ adsorption at liquid $\mathrm{N}_{2}$ temperature. Chemical analyses were performed by atomic absorption.

\section{RESULTS AND DISCUSSION}

Starting from the $\mathrm{CrO}_{1.9}$ oxides, it was only possible to obtain $\mathrm{Cr}$ particles containing less than $0.5 \mathrm{wt} \%$ of oxygen with a $\mathrm{H}_{2}$ reduction after $6 \mathrm{~h}$ at a temperature as high as $1300^{\circ} \mathrm{C}$. 
TABLE 3

Phases Detected by XRD after Treating the $\mathrm{Cr}_{3} \mathrm{C}_{2}$ Powders in $\mathrm{H}_{2}$ at $1000^{\circ} \mathrm{C}$ for Different Times

\begin{tabular}{cccc}
\hline & \multicolumn{3}{c}{$\begin{array}{c}\text { Needles and } \\
\text { rods }\end{array}$} \\
\hline 1 & Spheres & \multicolumn{1}{c}{ Polyhedra } \\
\hline 2 & $\mathrm{Cr}_{23} \mathrm{C}_{6}$ & $\mathrm{Cr}_{7} \mathrm{C}_{3}$ & $\mathrm{Cr}_{7} \mathrm{C}_{3}$ \\
4 & $\mathrm{Cr}_{23} \mathrm{C}_{6}$ & $\mathrm{Cr}_{7} \mathrm{C}_{3}+\mathrm{Cr}_{23} \mathrm{C}_{6}$ & $\mathrm{Cr}_{7} \mathrm{C}_{3}+\mathrm{Cr}_{23} \mathrm{C}_{6}$ \\
5 & $\mathrm{Cr}_{23} \mathrm{C}_{6}+\mathrm{Cr}$ & $\mathrm{Cr}_{7} \mathrm{C}_{3}+\mathrm{Cr}_{23} \mathrm{C}_{6}$ & $\mathrm{Cr}_{7} \mathrm{C}_{3}+\mathrm{Cr}_{23} \mathrm{C}_{6}$ \\
6 & $\mathrm{Cr}_{23} \mathrm{C}_{6}+\mathrm{Cr}$ & $\mathrm{Cr}_{23} \mathrm{C}_{6}$ & $\mathrm{Cr}_{7} \mathrm{C}_{3}+\mathrm{Cr}_{23} \mathrm{C}_{6}$ \\
8 & $\mathrm{Cr}$ & $\mathrm{Cr}_{23} \mathrm{C}_{6}+\mathrm{Cr}$ & $\mathrm{Cr}_{23} \mathrm{C}_{6}$ \\
10 & - & $\mathrm{Cr}_{23} \mathrm{C}_{6}+\mathrm{Cr}$ & $\mathrm{Cr}_{23} \mathrm{C}_{6}+\mathrm{Cr}$ \\
12 & - & $\mathrm{Cr}$ & $\mathrm{Cr}_{23} \mathrm{C}_{6}+\mathrm{Cr}$ \\
\hline
\end{tabular}

Furthermore, SEM observations (Fig. 1) show that the so-obtained $\mathrm{Cr}$ particles exhibit an ill-defined morphology, which is due to some sintering during the treatment. No difference in the reduction behavior was observed between the polyhedral and spherical powders despite the difference in specific surface area $\left(185\right.$ and $320 \mathrm{~m}^{2} / \mathrm{g}$, respectively).

The spherical $\mathrm{Cr}_{3} \mathrm{C}_{2}$ powders of different specific surface area $\left(1,4\right.$, and $12 \mathrm{~m}^{2} / \mathrm{g}$, hereafter denoted as powders $\mathrm{S} 1, \mathrm{~S} 4$, and $\mathrm{S} 12$, respectively) were heat-treated in $\mathrm{H}_{2}$ for $2 \mathrm{~h}$ at different temperatures ranging between 500 and $1000^{\circ} \mathrm{C}$. The phases detected by XRD patterns analysis are reported in Table 2. When starting from the $\mathrm{S} 1 \mathrm{Cr}_{3} \mathrm{C}_{2}$ powder, $\mathrm{Cr}_{3} \mathrm{C}_{2}$ is still the only phase detected in the XRD patterns of products reduced a temperatures lower than $900^{\circ} \mathrm{C}$. A mixture of $\mathrm{Cr}_{3} \mathrm{C}_{2}$ and $\mathrm{Cr}_{7} \mathrm{C}_{3}$ is detected for specimens reduced at 900, 950, and $1000^{\circ} \mathrm{C}$. Starting from $\mathrm{S} 4, \mathrm{Cr}_{7} \mathrm{C}_{3}$ is detected in addition to $\mathrm{Cr}_{3} \mathrm{C}_{2}$ after the 800,850 , and $900^{\circ} \mathrm{C}$ treatments and is the sole phase detected after the 950 and $1000^{\circ} \mathrm{C}$ treatments. As expected, the reactivity of the S12 powder is higher than that of S1 or S4. Indeed, the S12 $\mathrm{Cr}_{3} \mathrm{C}_{2}$ (Fig. 2a) is gradually transformed into $\mathrm{Cr}_{2} \mathrm{C}$, which is the sole product detected in the powder treated at $650^{\circ} \mathrm{C}$ (Fig. $2 \mathrm{~b}$ ). $\mathrm{Cr}_{2} \mathrm{C}$ is then transformed into $\mathrm{Cr}_{7} \mathrm{C}_{3}$ (obtained at $850^{\circ} \mathrm{C}$, Fig. 2c), which in turn yields $\mathrm{Cr}_{23} \mathrm{C}_{6}$ at $1000^{\circ} \mathrm{C}$ (Fig. 2d).

In agreement with Leclercq et al. [12], we observed that decarburization occurs before a complete removal of the excess free carbon; indeed, the amount of free carbon in the S12 $\mathrm{Cr}_{3} \mathrm{C}_{2}$ was found to be $1.5 \mathrm{wt} \%$, whereas it decreases to $0.8 \mathrm{wt} \%$ in the product treated at $500^{\circ} \mathrm{C}, 0.3 \mathrm{wt} \%$ in $\mathrm{Cr}_{2} \mathrm{C}$, and $0 \mathrm{wt} \%$ in $\mathrm{Cr}_{7} \mathrm{C}_{3}$ and $\mathrm{Cr}_{23} \mathrm{C}_{6}$. It should be noted that the proportion of extra carbon in our $\mathrm{Cr}_{3} \mathrm{C}_{2}$ powder is much lower than that reported by Leclercq et al. [12].

To achieve the obtention of $\mathrm{Cr}$ at $1000^{\circ} \mathrm{C}$, the $\mathrm{S} 12$ spherical $\mathrm{Cr}_{3} \mathrm{C}_{2}$ and the differently shaped $\mathrm{Cr}_{3} \mathrm{C}_{2}$ powders (needles, rods and polyhedra), which have a similar specific surface area (ca. $10 \mathrm{~m}^{2} / \mathrm{g}$ ), were heat-treated in $\mathrm{H}_{2}$ for different times ranging between 1 and $12 \mathrm{~h}$. The results are summarized in Table 3 and the XRD patterns of the powders obtained from the spherical carbide are shown in Figure 3.

Whatever the morphology of the starting $\mathrm{Cr}_{3} \mathrm{C}_{2}$ powder, it is possible to prepare $\mathrm{Cr}_{7} \mathrm{C}_{3}$, $\mathrm{Cr}_{23} \mathrm{C}_{6}$, and $\mathrm{Cr}$, or to obtain mixtures of these compounds, depending on the dwell time. It appears that the spheres and polyhedra are the most and least reactive powders, respectively, and that the needles and rods have an intermediate behavior upon reduction, similar to each other. Indeed, $\mathrm{Cr}_{23} \mathrm{C}_{6}$ is obtained after treatments of $1 \mathrm{~h}$ (spheres), $5 \mathrm{~h}$ (needles and rods), and 


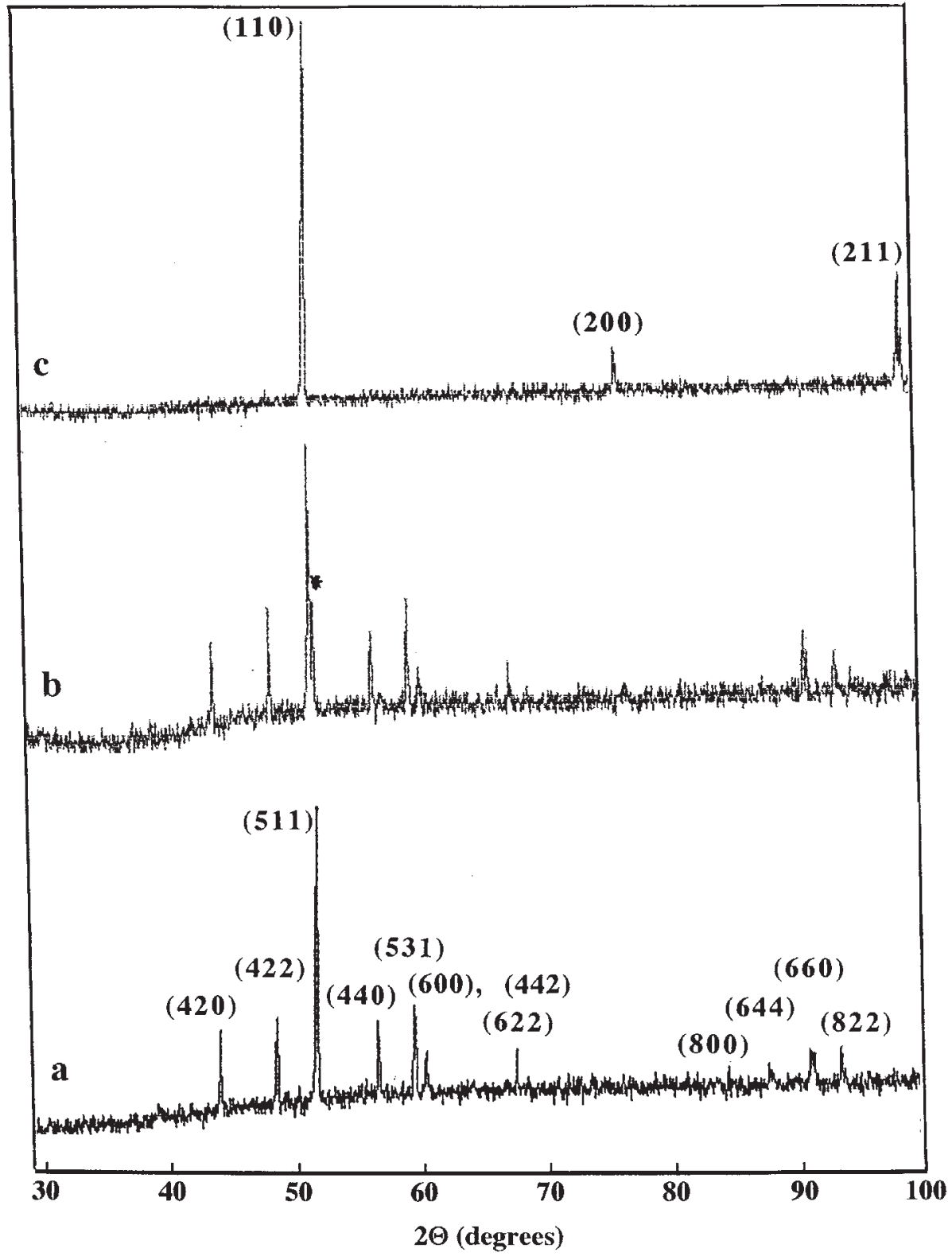

FIG. 3

XRD patterns of some of the products obtained from the spherical $\mathrm{Cr}_{3} \mathrm{C}_{2}$ powder $\mathrm{S} 12$ heat-treated in $\mathrm{H}_{2}$ at $1000^{\circ} \mathrm{C}$ for (a) $1 \mathrm{~h}\left(\mathrm{Cr}_{23} \mathrm{C}_{6}\right)$, (b) $4 \mathrm{~h}\left(\mathrm{Cr}_{23} \mathrm{C}_{6}+\mathrm{Cr}\right)$, and (c) $6 \mathrm{~h}(\mathrm{Cr})$.

$6 \mathrm{~h}$ (polyhedra), and $\mathrm{Cr}$ is obtained after treatments of $6 \mathrm{~h}$ (spheres), $10 \mathrm{~h}$ (needles and rods), and $12 \mathrm{~h}$ (polyhedra).

The pseudomorphic nature of the transformation is evidenced by SEM observations. Indeed, we obtained $\mathrm{Cr}_{7} \mathrm{C}_{3}, \mathrm{Cr}_{23} \mathrm{C}_{6}$, and $\mathrm{Cr}$ powders in the shape of needles, rods, polyhedra, and spheres (Fig. 4). The $\mathrm{Cr}$ needles and rods are, however, very similar to each other. The size distribution seems rather narrow and the powders are not aggregated. The particle size distributions (in number) were derived from measurements of SEM images (Fig. 5). Depending on the shape, the average particle size is of the order of some micrometers (polyhedra, spheres) or some tens of micrometers (needles, rods). The length distribution of the $\mathrm{Cr}_{3} \mathrm{C}_{2}$ and $\mathrm{Cr}$ powders in the form of needles and rods (Figs. 5a, b, e, and f) is, in fact, 


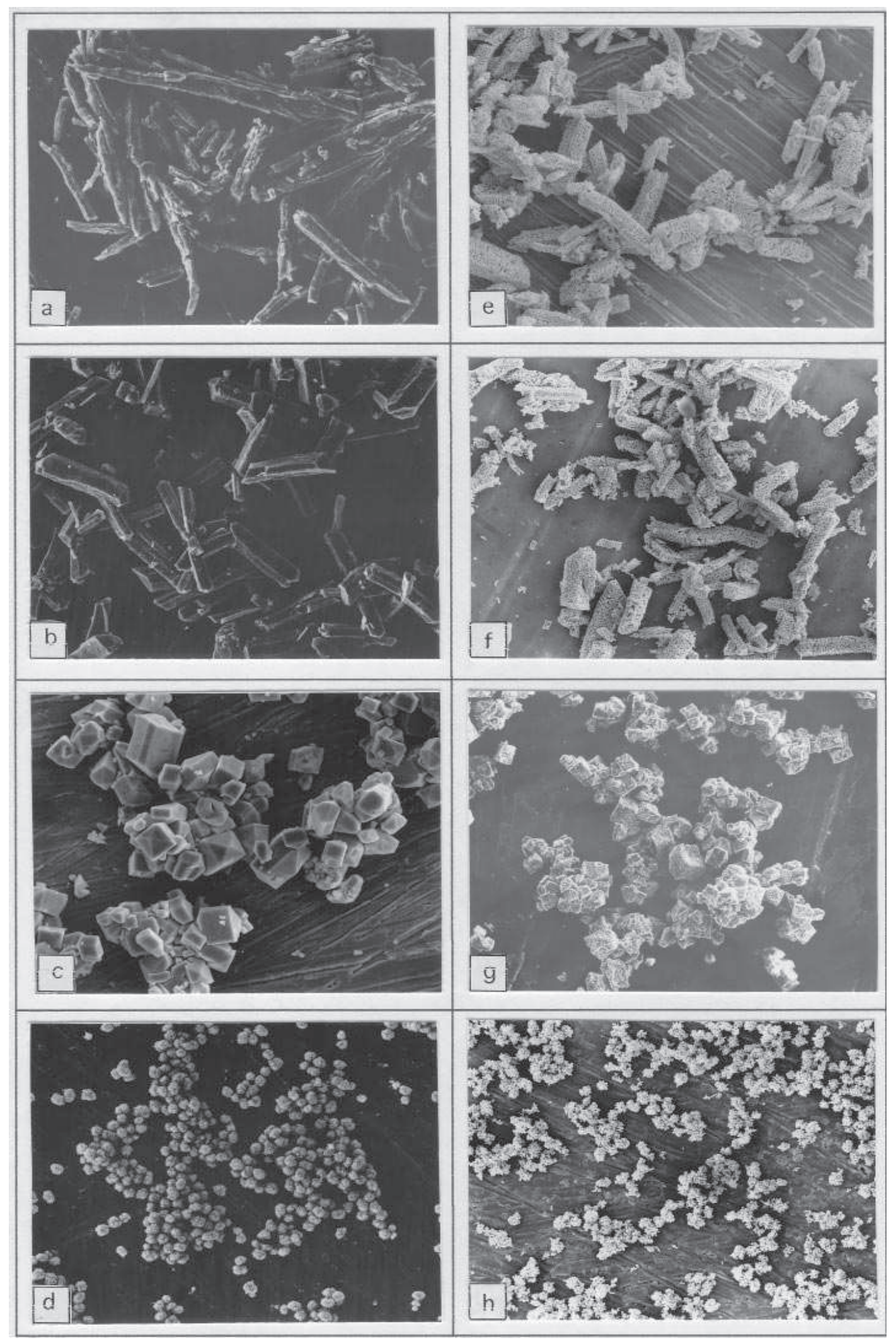

FIG. 4

SEM images of $\mathrm{Cr}_{3} \mathrm{C}_{2}$ powders showing different shapes - needles (a), rods (b), polyhedra (c), and spheres (d) - and the corresponding Cr powders (e, f, g, and h, respectively). The $\mathrm{Cr}$ needles and rods are very similar. 

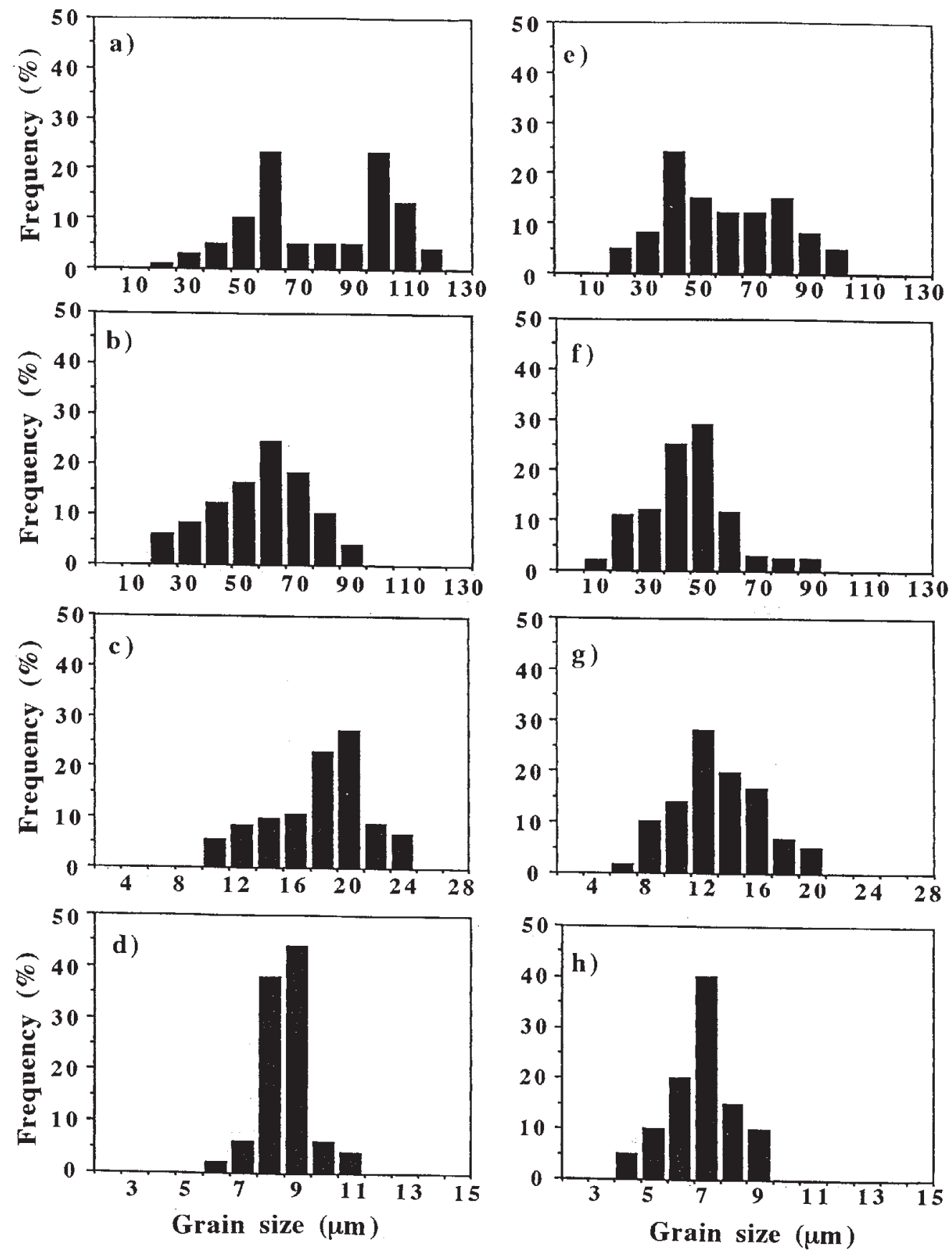

FIG. 5

Size distribution of the different $\mathrm{Cr}_{3} \mathrm{C}_{2}$ powders - needles (a), rods (b), polyhedra (c), and spheres (d) - and the corresponding $\mathrm{Cr}$ powders (e, f, g, and h, respectively).

large and bimodal because some needles/rods have been broken at some point during the manipulations. The size distribution is much narrower for the polyhedra and, in particular, for the spheres (Figs. 5c, d, g, h).

The Cr particles are slightly smaller than those of the parent $\mathrm{Cr}_{3} \mathrm{C}_{2}$, because the reduction treatment provokes a coalescence of the primary crystallites, in addition to the decarburization, on the one hand, and a shrinkage of the grains, on the other hand, as shown in the case 

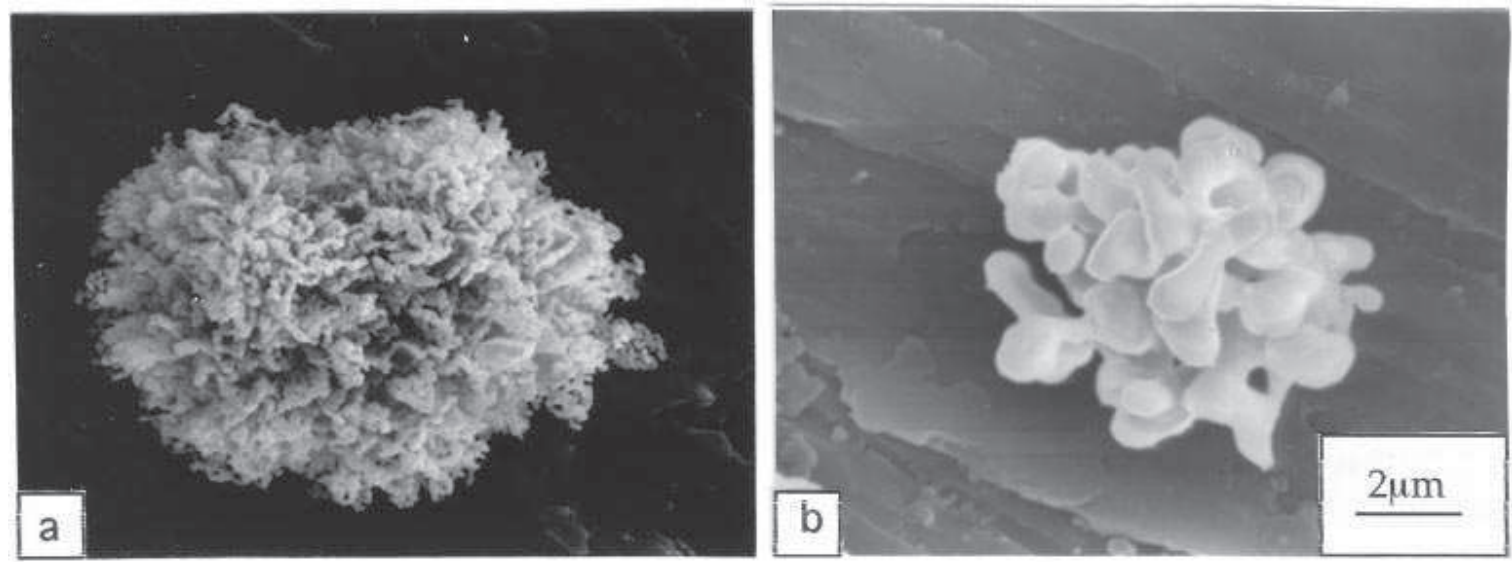

FIG. 6

Higher magnification SEM images showing the spherical $\mathrm{Cr}_{3} \mathrm{C}_{2}$ (a) and $\mathrm{Cr}$ powders (b).

of spheres by SEM observations (Fig. 6). It should be noted that the average size of a given powder $\left(\mathrm{CrO}_{1.9}, \mathrm{Cr}_{3} \mathrm{C}_{2}, \mathrm{Cr}_{2} \mathrm{C}, \mathrm{Cr}_{7} \mathrm{C}_{3}, \mathrm{Cr}_{23} \mathrm{C}_{6}\right.$, or $\left.\mathrm{Cr}\right)$ depends on that of the parent Cr oxalate, which can be varied by minor modifications of the precipitation process.

The difference in reactivities among the various $\mathrm{Cr}_{3} \mathrm{C}_{2}$ powders is not due to differences in their specific surface areas, which are similar to each other (ca. $10 \mathrm{~m}^{2} / \mathrm{g}$, Table 1), but rather in their texture. Indeed, in contrast to the other specimens, which are more monolithical, the spherical grains are made up of fine crystallites $(100 \mathrm{~nm})$ forming a kind of "gypsum flower" texture (Fig. 6a), favor $\mathrm{H}_{2}$ diffusion and removal of the gaseous species in this material. Similar results were observed for the reoxidation behavior of the $\mathrm{Cr}_{3} \mathrm{C}_{2}$ powders [10].

\section{CONCLUSIONS}

Powders of different morphology (needles, rods, polyhedra and spheres) of the metastable chromium oxide $\mathrm{CrO}_{1.9}$ and of $\mathrm{Cr}_{3} \mathrm{C}_{2}$ have been prepared by the appropriate heat treatments of the corresponding $\mathrm{Cr}$ oxalate precursors. The hydrogen treatment of $\mathrm{Cr}_{3} \mathrm{C}_{2}$ allows preparation of $\mathrm{Cr}$ powders at a temperature $\left(1000^{\circ} \mathrm{C}\right)$ markedly lower than that required when $\mathrm{CrO}_{1.9}$ is used as the starting material $\left(1300^{\circ} \mathrm{C}\right)$. A carbide specific surface area of the order of $10 \mathrm{~m}^{2} / \mathrm{g}$ is necessary to achieve this within a reasonably short time $(6-12 \mathrm{~h})$. Due to these relatively mild experimental conditions, it is possible to obtain $\mathrm{Cr}$ powders of tailored morphology and with a narrow size distribution. Depending on the shape, the average particle size is of the order of some micrometers or some tens of micrometers. Similar powders of the lower carbides $\left(\mathrm{Cr}_{2} \mathrm{C}, \mathrm{Cr}_{7} \mathrm{C}_{3}\right.$, and $\left.\mathrm{Cr}_{23} \mathrm{C}_{6}\right)$ can be prepared using still milder thermal treatments. A controlled morphology would be essential if these powders were to be used for preparing coatings by electrodeposition.

\section{REFERENCES}

1. L.E. Toth, Transition Metal Carbides and Nitrides, Academic Press, New York (1971).

2. G.G. Ferrier, A.R. Berzins, and N.M. Davey, Platinum Metals Rev. 29, 175 (1985).

3. G.P. Demopoulos and G. Pouskouleli, J. Metals 40, 46 (1988). 
4. Y. Zenira, in Precious Metals 1986, ed. U.V. Rao, p. 409, IPMI, Allentown, PA (1986).

5. F. Fievet, J.P. Lagier, and M. Figlarz, MRS Bull. 24, 29 (1989).

6. E. Matijevic, Faraday Discuss. 92, 229 (1991).

7. S. Komarneni, R. Pidugu, Q.H. Li, and R. Roy, J. Mater. Res. 10, 1687 (1995).

8. D. Thibaudon, M. Roubin, R.A. Paris, and J. Paris, Planseeber. Pulvermetal. 20, 129 (1972).

9. A. Lerch and A. Rousset, Thermochim. Acta 232, 233 (1994).

10. S. Loubière, Ch. Laurent, J.P. Bonino, and A. Rousset, Mater. Res. Bull. 30, 1535 (1995).

11. S. Loubière, Ch. Laurent, J.P. Bonino, and A. Rousset, J. Alloys Compd. 243, 59 (1996).

12. G. Leclercq, M. Kamal, J.-F. Lamonier, L. Feigenbaum, P. Malfoy, and L. Leclercq, Appl. Catal., A: General 121, 169 (1995). 